\title{
A Procedural Framework for the Disclosure of Business Records Under the Freedom of Information Act
}

In the exercise of their regulatory, investigatory, and general administrative responsibilities, federal agencies obtain from American businesses an enormous amount of material containing detailed commercial and financial information. ${ }^{1}$ A sizeable portion of this accumulated data is of little or no commercial value, but in many cases businesses have a substantial stake in keeping secret the information they submit to a federal agency. ${ }^{2}$ As a result, a consid-

1. See, e.g., Brief Amicus Curiae on Behalf of the Chamber of Commerce of the United States at 4-6, Chrysler Corp. v. Brown, 441 U.S. 281 (1979) (providing examples of business secrets in agency files); House Comm. on Government Operations, Freedom of INformation ACt Requests for Business Data and Reverse-FOIA Lawsuits, H.R. Rep. No. 1382, 95th Cong., 2d Sess. 1, 13-14 (1978) (explaining business data requirements of federal agencies) [hereinafter cited as 1978 FOIA REPORT]; Freedom of Information Act: Hearings Before the Subcomm. on Administrative Practice and Procedure of the Senate Comm. on the Judiciary, 95th Cong., 1st Sess. 293, 294 (1977) (statement of Burt A. Braverman, attorney) ("vast array of private information" in possession of agencies) [hereinafter cited as 1977 Senate Hearings].

2. For example, public disclosure of a business' Equal Employment Opportunity (EEO) "manning" tables, which detail the racial and sexual composition of a particular workforce and are required to be submitted by all government contractors under Exec. Order No. 11,246, 3 C.F.R. 339 (1964-1965 Compilation) (amended version at 42 U.S.C. $\$ 2000 e$ app., at 392 (Supp. III 1979)), could have undesirable commercial consequences, because other companies might analyze and exploit the information and thereby obtain a competitive advantage. See Chrysler Corp. v. Schlesinger, 412 F. Supp. 171, 176 (D. Del. 1976), vacated, 565 F.2d 1172 (3d Cir. 1977), vacated and remanded sub nom. Chrysler Corp. v. Brown, 441 U.S. 281 (1979). In addition to these competitive disadvantages, businesses seek to avoid other deleterious consequences. Public interest groups might publicize the data in order to expose the business' affirmative action failures, see Natural Resources Defense Council, Inc. v. SEC, 432 F. Supp. 1190, 1209-12 (D.D.C. 1977), rev'd, 606 F.2d 1031 (D.C. Cir. 1979), and litigious unions and employees might use the statistics to challenge the business' hiring and promotion practices, see Westinghouse Elec. Corp., 239 N.L.R.B. 106, 110-11 (1978), modified and enforced sub nom. IUE v. NLRB, No. 78-2067 (D.C. Cir. Nov. 28, 1980). See generally Connolly \& Fox, Employer Rights and Access to Dacuments Under the Freedom of Information Act, 46 Fordham L. REv. 203, 203-07 (1977) (discussing attempts by various parties to obtain EEO reports).

Businesses can advance a claim of confidentiality with respect to much of the information that government collects from them. See, e.g., Mobile Infirmary Ass'n v. Harris, 1 Gov't Disclosure (P-H) I 79,197 (S.D. Ala. Sept. 28, 1979) (Medicare Provider Cost reports); Jones, Day, Reavis \& Pogue, Washington, D.C., 4 DOE (CCH) 9 80,146 (Sept. 7, 1979) (energy-related information); 1978 FOIA REPORT, supra note 1, at 7-8 (citing other examples); McGarity \& Shapiro, The Trade Secret Status of Health and Safety Testing Information: Reforming Agency Disclosure Policies, 93 Harv. L. REv. 837, 849-51 (1980) (results of 
erable dispute has developed in recent years over the extent to which federal agencies may release commercially sensitive business documents pursuant to a Freedom of Information Act (FOIA) ${ }^{3}$ request. ${ }^{4}$

This Note argues that existing legal doctrines have failed adequately to reconcile the conflicting principles of disclosure and nondisclosure at the heart of the current business records controversy. At present, agencies possess too much discretion to withhold information arbitrarily and not enough discretion to disclose it under appropriate circumstances, with the result that the principle of disclosure is often sacrificed to that of nondisclosure. The Note applies procedural techniques from the civil discovery and the FOIA personal privacy contexts to fashion a more coherent approach to the disclosure of government-held business documents. This approach would require agencies to balance, in each particular case, all of the interests, both public and private, at stake in any disclosure or nondisclosure decision. It would maximize the potential for the disclosure of business records without unduly impinging upon the interests of those who supply business information to the government.

\section{The Legal Evolution of the Business Records Controversy}

In 1966, after many years of hearings and debates, ${ }^{5}$ Congress adopted the Freedom of Information Act, a legislative effort to re-

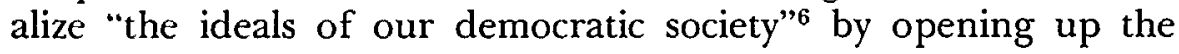

drug, pesticide, and toxic substance tests); Note, The Freedom of Nonfree Information: An Economic Proposal for Government Disclosure of Privately Submitted Commercial Information, 32 STAN. L. REv. 339,339 n.3 (1980) (citing cases).

3. 5 U.S.C. $\$ 552$ (1976 \& Supp. III 1979).

4. Ste generally Fredom of Information, Sunshine, and Privacy Laws: Impact on Business, 34 Bus. LAw. 977 (1979); O'Reilly, Government Disclosure of Private Secrets Under the Freedom of Information Act, 30 Bus. Law. 1125 (1975); Patten \& Weinstein, Disclosure of Business Secrets Under the Frtedom of Infornation Act: Suggested Limitations, 29 AD. L. REv. 193 (1977); Wallace, Propur Disclosure and Indecent Exposure: Protection of Trade Secrets and Confidential Commrrial Information Supplied to the Government, 34 FED. B.J. 295 (1975).

5. Ste, t.g., Administrative Procedure Act: Hearings Before the Subcomm. on Administrative Practice and Proctdure of the Stnate Comm. on the Judiciary, 89th Cong., 1st Sess. (1965); Fed'ral Public Records Law: Hearings Before a Subcomm. of the House Comm. on Government Operatiurs, 89th Cong., 1st Sess. (1965); Freedom of Information: Hearings Before the Subcomm. on Adminisirativ' Practice and Procedure of the Senate Comm. on the Judiciary, 88th Cong., 1st Sess. (1963); Arailability of Information from Federal Departments and Agencies: Hearings Before a Subcomm. of the House Comm. on Government Operations, 84th Cong., 1st \& 2d Sess. (1955-1956).

6. H.R. ReP. No. 1497, 89th Cong., 2d Sess. 12 (1966), reprinted in [1966] U.S. CodE CONG. \& Ad. News 2418, 2429 [hereinafter cited as 1966 House Report with page citations to U.S. Code Cong. \& Ad. News]. 
decisionmaking processes of the federal agencies to public scrutiny. ${ }^{7}$ The Act reversed the presumption of secrecy that had been accorded to agency-held records ${ }^{8}$ and required each agency to make available to "any person" upon request any of the records within its possession, ${ }^{9}$ unless a requested document fell within a number of narrowly drawn statutory exemptions. ${ }^{10}$ One such exemption, added by Congress almost as an afterthought, ${ }^{11}$ relates solely to government-held business records. According to subsection 552(b)(4), the provisions of the Act do not apply to "trade secrets and commercial or financial information obtained from a person and privileged or confidential." 12

7. S. ReP. No. 813 , 89th Cong., lst Sess. 2, 3, 10 (1965) [hereinafter cited as 1965 SENate Report]. For a general discussion of the FOIA, see The Center for National SecuRity Studies, The 1980 Edition of Litigation Under the Federal Freedom of Information ACt and Privacy ACt (5th ed. 1979); J. O'Reilly, Federal Information DiscloSURE: Procedures, Forms and THE LAw 1-1 to 19-6 (1977); Davis, The Information Act: $A$ Preliminary Analysis, 34 U. CHI. L. Rev. 761 (1967).

8. The FOIA replaced section 3 of the Administrative Procedure Act, ch. $324, \$ 3,60$ Stat. 237 (1946), which provided that, with certain exceptions, "matters of official record shall . . . be made available to persons properly and directly concerned." In practice, few individuals were able to satisfy that standard. Moreover, the statutory exceptions to section 3 were quite broad (for example, the section did not apply to "any function of the United States requiring secrecy in the public interest," $i d$. , and did not require an agency to disclose "information held confidential for good cause," $i d . \S 3(\mathrm{c})$ ) and were invoked repeatedly by federal agencies seeking to deny requests for information. 1966 House $R_{E-}$ PORT, supra note 6, at 2418-23; 1965 SENATE REPORT, supra note 7, at 3-5. See J. O'ReILlY, supra note 7, § 2.02 (discussing interpretation of section 3); Marson, Obtaining Access to Information in the Files of Government Agencies: Discussion, 34 Bus. Law. 1003, 1003-04 (1979) (criticizing section 3 standard). Prior to the FOIA, agencies generally released business information within their files only in response to specific legislative mandates that had been fashioned in order to remedy particular problems. See $1 \mathrm{~K}$. Davis, Administrative Law TREATISE $\$ 3.13$, at 226 (1958); J. O'ReIlly, supra note 7, \$ 14.02, at 14-3.

9. 5 U.S.C. $\$ 552(a)(3)(1976)$.

10. Id. $\$ 552$ (b); see 1966 HouSE REPORT, supra note 6, at 2426-29 (explaining nine exemptions in subsection (b)); 1965 SENATE REPORT, supra note 7, at 8-10 (same).

11. As originally drafted, the FOIA contained no exemption for business records. In response to concerns voiced by both businesses and agencies during hearings on the proposed Act, however, the Senate Judiciary Committee attached a provision which ultimately became known as the "business records exemption." For a discussion of the legislative history of the exemption, see National Parks \& Conservation Ass'n v. Morton, 498 F.2d 765, 766-70 (D.C. Cir. 1974).

12. 5 U.S.C. $\$ 552(b)(4)$ (1976). Subsection (b)(4) has generated numerous problems of statutory interpretation. See 1978 FOIA REPORT, supra note 1, at 15-19. Under the prevailing interpretation, the term "confidential" refers to business information the disclosure of which would either "impair" an agency's access to such "necessary information" in the future or subject the submitter of such information to "substantial" competitive harm. National Parks \& Conservation Ass'n v. Morton, 498 F.2d 765, 770 (D.C. Cir. 1974).

The National Parks test has attracted its share of criticism. See Koch \& Rubin. A Proposal for a Comprehensive Restructuring of the Public Information System, 1979 DukE L.J. 1, 54 (National Parks standard "fundamentally ambiguous"); Patten \& Weinstein, supra note 4, at 195-202 (better approach would focus on customary treatment given to information by its owner). Despite this criticism, however, National Parks remains the benchmark from which 


\section{Business Records}

Despite the (b)(4) exemption, the enactment of the FOIA made available directly from the government a great deal of previously undisclosed business information simply upon the request of any interested party. ${ }^{13}$ As an increasing number of individuals and organizations resorted to the FOIA in order to acquire business documents, an increasing number of complaints were voiced by business representatives. In particular, it was alleged that the Act had come to be used as a tool for industrial espionage ${ }^{14}$ and was being employed to "pry business secrets from Uncle Sam's files"15 merely "for the price of a postage stamp." 16 Some observers charged, moreover, that agency officials, insensitive to commercial and competitive realities, failed to recognize the harms-both to the particular business involved and to the economy as a whole-that followed upon the forced disclosure of any business document. ${ }^{17}$

all analysis of subsection (b)(4) must proceed. See Note, The Reverse-FOIA Lausuit: Routes to Nondisclusurt After Chrysler, 46 Brooklyn L. Rev. 269, 289-90 (1980).

13. St' Business Record Exemption of the Freedom of Information Act: Hearings Before a Subcamm. of the House Comm. on Govermment Operations, 95th Cong., 1st Sess. 98, 111 (1977) (statement of Burt A. Braverman, attorney) ("competitors, analysts, investors, disgruntled employees, potential and existing adverse litigants, self-styled 'public interest' groups, foreign businesses and governments and a wide variety of others" employ FOIA to obtain private business information otherwise unavailable) [hereinafter cited as 1977 House Hearings]; Wallace, supra note 4 , at 295 (FOIA increases risk of disclosure of valuable commercial information).

14. S $x^{\prime}$ Brief Amicus Curiae on Behalf of the Chamber of Commerce of the United States at 7-10, Chrysler Corp. v. Brown, 441 U.S. 281 (1979) (FOIA employed as "vehicle for industrial espionage"); 1977 Senate Hearings, supra note 1, at 3, 4 (statement of Sherwin Gardner, Deputy Commissioner, FDA) (FOIA used as means of corporate intelligence gathering); English, Protecting the Stakeholder: Defense of the Govermment Agency's Interests Durmg R $R_{\text {it }} r_{\text {s }}$ FOIA Lawsuits, 31 AD. L. REv. 151, 152-53 (1979) (majority of FOIA requests submitted by businesses engaged in some form of industrial espionage); Montgomery, Peters, \& Weinberg. The Freedom of Information Act: Strategic Opportunities and Threats, SLoAN MANAGEMENT REV., Winter 1978, at 1-13 (discussing impact of FOIA on competitive envirunment).

According to the General Accounting Office, in 1977 nearly half of all FOIA requests received by surveyed agencies were submitted by businesses. This figure would be even higher if requests submitted on behalf of businesses by law firms and other representatives were included. General Accounting Office, Report by the Comptroller General of the United States, Government Field Offices Should Better Implement the FreeDOM OF INFORMATION ACT 37 (1978) (No. LCD-78-120) [hereinafter cited as GAO FOIA REPORT]. For some agencies, the percentage of industry-generated FOIA applications topped $80 \%$. See $z$. at 38 (Farmers Home Administration); Koch \& Rubin, supra note 12, at 17 n.54 (FDA).

15. Schorr, Telling Tales: How Law is Being Used to Pry Business Secrets From Uncle Sam's Fils's, Wall St. J., May 9, 1977, at 1, col. 6.

16. 1977 Houst Hearings, supra note 13, at 98, 111 (statement of Burt A. Braverman, attorney).

17. St' O'Reilly, Trade Secret Protection Under the Freedom of Information Act and Related Staluts, in Protecting and Profming from Trade Secrets 1979, at 283, 292 (R. Milgrim 
Some commentators doubted whether much corporate spying actually was taking place under the auspices of the FOIA. ${ }^{18}$ Other commentators contended that a different, largely unexpressed concern was at the root of most business opposition to the FOIA. Information had been sought from the government, often by public interest organizations, concerning the enforcement by certain agencies of specific public policies and the compliance with those policies by certain businesses. ${ }^{19}$ It was suggested that public dissemination of such information might subject a business to otherwise avoidable litigation and embarrassment. ${ }^{20}$

Whatever their actual motives, business submitters of confidential information began to sue federal agencies to enjoin them from releasing the information to any third-party requester under the FOIA. ${ }^{21}$ Agencies, courts, and commentators struggled to answer

ed. 1979) ("publicity-conscious" federal employees not responsive to claims of business confidentiality); Patten \& Weinstein, supra note 4, at 203 (agencies lack expertise needed to analyze possible competitive consequences of disclosure); (f. 1977 Senate Hearings, supra note 1, at 39, 42 (testimony of Charles W. Stewart, President, Machinery \& Allied Products Institute) (due to administrative burden of FOIA, great incentive on part of "bureaucratic people" to disclose business documents).

18. See, e.g., Stevenson, FOIA Trade Secret Exemption: Are Problems Real? Legal Times of Washington, Nov. 10, 1980, at 16, col. 1; cf. 1977 Senate Hearings, supra note 1, at 15, 16 (testimony of Michael A. James, Deputy General Counsel, EPA) (EPA refuses to override company's claim of confidentiality unless provided with "very good basis" for doing so); Saloschin \& Pitt, Disclosure to Third Parties of Information Filed With Govermment Agencies: The Agencies' Perspective, 34 Bus. LAw. 1061, 1064 (1979) (statement of Robert L. Saloschin, Chairman, Freedom of Information Committee, U.S. Dep't of Justice) (agencies afford greater protection to business records than to national security information). One congressional committee noted that specific instances of corporate espionage activity under the Act were hard to document. 1978 FOIA REPORT, supra note 1, at 11 . Other commentators contended that corporate spying, if it occurs, is unobjectionable because it enhances competition. See Redburn, A Study in Fraudulent Fairness, BarRISTER, Fall 1975, at 22 (quoting Mark Green, consumer activist).

19. See, e.g., GTE Sylvania, Inc. v. Consumers Union, 445 U.S. 375 (1980) (suit by Consumers Union and Public Citizen's Health Research Group for television manufacturers' accident reports submitted to Consumer Product Safety Commission); Public Citizen Health Research Group v. HEW', 477 F. Supp. 595 (D.D.C. 1979) (suit by Public Citizen Health Research Group for reports on federally funded medical services required by HEW); Brief of Amici Curiae Consumer Federation of America, Women's Equity Action League, Mexican American Legal Defense and Educational Fund, and Women's Legal Defense Fund at 13 n.20, Chrysler Corp. v. Brown, 441 U.S. 281 (1979) (virtually all reverscFOIA cases originated after requests from "ordinary citizens or citizen groups working on behalf of consumers or minorities and women"). EEO manning tables, see note 2 supra, are among the most sought-after government-held business documents. See note 22 infra.

20. See note 2 supra; Hughes Aircraft Co. v. Schlesinger, 384 F. Supp. 292, 297 (C.D. Cal. 1974) (business feared embarrassment from disclosure of its affirmative action plan).

21. See Campbell, Reverse Freedom of Information Act Litigation: The Need for Congressional Action, 67 Geo. L.J. 103, 107 n.28, 108 n.29 (1978) (collecting cases). The plaintiff business usually advanced any or all of the following arguments in support of a court order of nondisclosure: that the information requested was exempt from mandatory disclosure under subsection (b)(4) of the FOIA; that subsection (b)(4) was a mandatory nondisclosure 


\section{Business Records}

two basic questions: Could an agency, pursuant to an FOIA request, release a business document that fell within the terms of subsection (b)(4) - that is, that contained either trade secrets or confidential commercial or financial information? If so, what standards, if any, were to govern an agency's release of that document? After several years of reverse-FOIA litigation, ${ }^{22}$ and after a recent, unanimous Supreme Court decision, ${ }^{23}$ four broad doctrines have emerged in response to these questions.

First, the courts have concluded, almost without dissent, that subsection (b)(4) does not of itself bar an agency from releasing business documents within its possession; rather, the (b)(4) exemption, as well as each of the other FOIA exemptions, simply gives an agency the discretion to reject certain FOIA requests if it so desires. ${ }^{24}$ As the Supreme Court declared in Chrysler Corp. v. Brown, "Congress did not limit an agency's discretion to disclose information when it enacted the FOIA."25 Exemption (b)(4) "demarcates the agency's obligation to disclose" confidential commercial and financial information, but does not itself "foreclose disclosure."26

Second, the courts have concluded that, just as nothing in the FOIA bars an agency from releasing exempt business records, so too nothing in the Act obligates an agency to disclose exempt information, or even to consider making such disclosures. ${ }^{27}$ Once an

provision and thus barred an agency from releasing confidential business records to which it might enjoy access; that disclosure of the material in question would violate a federal statute such as the Trade Secrets Act; that irreparable harm would result to the submitter if the FOIA request were honored; and that release of the requested information would constitute an abuse of agency discretion.

For a general discussion of reverse-FOIA suits, see 1978 FOIA REPORT, supra note 1, at 53-67; Clement, The Rights of Submitters to Prevent Agency Disclosure of Confidential Business Information: The Reverse Freedom of Information Act Lawsuit, 55 TEX. L. REv. 587, 591-633 (1977).

22. According to the Department of Justice, 76 reverse-FOIA cases were filed in 1976 and 63 in 1977. As of May 1978, 104 reverse-FOIA cases were pending in the federal courts, with 34 involving EEO forms, 33 involving commercial information, and 20 involving Medicare cost reports. 1978 FOIA REPORT, supra note 1, at 54.

23. Chrysler Corp. v. Brown, 441 U.S. 281 (1979).

24. S $\ell^{\prime}$ Chrysler Corp. v. Brown, 441 U.S. 281, 290-94 (1979); Charles River Park "A", Inc. v. HUD, 519 F.2d 935, 941 (D.C. Cir. 1975); Clement, supra note 21, at 597-602 (citing cases).

25. 441 U.S. 281,294 (1979).

26. Id. at 292. The Court found Chrysler's contention that the FOIA imposes on federal agencies affirmative duties to withhold from disclosure certain "nongovernmental" documents to be unsupported "by the language, logic, or history of the Act." Id. at 291. Congress did not limit an agency's discretion when it enacted the FOIA; therefore, it "necessarily follows that the Act does not afford Chrysler any right to enjoin agency disclosure" in a reverse-FOIA suit against the government. Id. at 294.

27. Ser NLRB v. Sears, Roebuck \& Co., 421 U.S. 132, 147-48 (1975) (court's inquiry into FOIA nondisclosure decision ends if document found to be exempt. because Act does 
agency has determined that a requested document need not be released under the mandatory disclosure provisions of the FOIA, no further efforts on its part are required. ${ }^{28}$ In practice, federal agencies repeatedly have invoked their nondisclosure powers in the business records context, ${ }^{29}$ and a court has yet to order an agency to disgorge commercially sensitive exempt material that the agency has chosen to withhold.

Third, although a federal agency's nondisclosure discretion is virtually absolute, its disclosure discretion is far from unconstrained. According to the Supreme Court, ${ }^{30}$ before an agency can release an exempt business record, it must find that such release would not violate the Trade Secrets Act (TSA), a criminal statute that imposes penalties upon any federal official who discloses a business' "trade secrets . . . [or] confidential statistical data" in the

not apply to such documents); Weisberg v. United States Dep't of Justice, 489 F.2d 1195, 1202-03 (D.C. Cir. 1973) (same); Church of Scientology v. United States Dep't of Justice, 410 F. Supp. 1297, 1301 n.15 (C.D. Cal. 1976), aff'd, 612 F.2d 417 (9th Cir. 1979) (FOIA permits agency to withhold information that court might disclose were it to balance equities); J. O’Rerlly, supra note 7, $\$ 9.05$, at 9-14 (court has no equitable authority to order disclosure if exemption applies; "[a]gency discretion against disclosure of legally exempt documents is not limited").

28. An agency's determination that a requested document falls within an FOLA exemption, however, must be made carefully. That determination cannot contain mere "conclusory and generalized allegations" in support of an exemption's applicability; rather, a "detailed analysis" as to why the automatic disclosure provisions of the FOIA do not apply is necessary. Vaughn v. Rosen, 484 F.2d 820, 826 (D.C. Cir. 1973), cert. denied, 415 U.S. 977 (1974). Pursuant to 5 U.S.C. $\$ 552(a)(4)(B)$, a court will order the disclosure of any material which an in camera examination reveals to be nonexempt at law. See, e.g., Brockway v. Department of Air Force, 518 F.2d 1184, 1189 (8th Cir. 1975) (statements did not constitute trade secrets or confidential commercial or financial information, although they could be withheld under another FOIA exemption); Washington Research Project, Inc. v. HEW, 504 F.2d 238, 244-45 (D.C. Cir. 1974), cert. denied, 421 U.S. 963 (1975) (noncommercial scientist's research design not protected under terms of subsection (b)(4)).

29. See Federal Information Tools, Alexandria, Virginia, 3 DOE (CCH) ๆ 80,163 (Apr. 30, 1979) (Department of Energy will not determine whether disclosure of exempt business documents might be in public interest); FDA Public Information, 21 C.F.R. $\$ 20.61$ (c) (1980) (FDA regulations bar disclosure of trade secrets or confidential commercial information); EPA Public Information, 40 C.F.R. § 2.119(b) (1980) (EPA regulations explicitly prohibit discretionary release of exempt (b)(4) documents); GAO FOIA REPORT, supra note 14 , at 22 (exemptions applied automatically by some agencies).

In 1977, the Attorney General urged that agencies "not withhold documents unless it is important to the public interest to do so, even if there is some arguable legal basis for the withholding." Letter from Griffin B. Bell to Heads of all Federal Departments and Agencies (May 5, 1977), reprinted in 2 Gov't Disclosure (P-H) 1 300,775. The Chairman of the Justice Department's Freedom of Information Committee, however, subsequently assured business representatives that "[ $t]$ he encouragement of discretionary releases in [the Attorney General's] letter is not aimed at the area of business confidentiality, but is aimed primarily at internal government deliberations under exemption 5." Saloschin \& Pitt, supra note 18, at 1061 (statement of Robert L. Saloschin).

30. Chrysler Corp. v. Brown, 441 U.S. 281, 294-301 (1979). 
absence of legal authorization. ${ }^{31}$ Further, unless an agency's disclosure regulations specifically have been contemplated or approved by Congress, they do not in themselves constitute sufficient "authoriz[ation] by law" under the TSA to justify the release of confidential business data. ${ }^{32}$

Although the precise parameters of the TSA and similar statutes $^{33}$ have yet to be spelled out, ${ }^{34}$ Chrysler's interpretation of the statute poses a substantial obstacle to discretionary agency disclosure efforts. If, despite the urging of some commentators, ${ }^{35}$ the

31. 18 U.S.C. $\$ 1905$ (1976). For a discussion of the legislative history of the TSA, see Clement, supra note 21 , at 607-13.

At the time of Chrysler, no employee of the United States had ever been convicted of violating section 1905 for action taken in accordance with agency guidelines or regulations. See U.S. Dep’t of Justice, United States Atrorneys' Manual § 9-2.025 (1980). Prior to Chrysler, courts and commentators had disagreed as to whether the TSA served as a limitation on the disclosure powers of federal agencies under the FOIA. See 1978 FOIA REPORT, supra note 1, at 57-59; Campbell, supra note 21, at 144-45; Clement, supra note 21, at 613-17; English, supra note 14, at 164 .

32. Chrysler Corp. v. Brown, 441 U.S. 281, 301-12 (1979). According to the Court, for an agency to satisfy section 1905's "authorized by law" standard, its disclosure decisions must be based either upon a statute, $i d$. at 306 , or upon regulations issued in accordance with a congressional "grant of legislative authority," $i d$. at 308. The Court rejected a number of other possible justifications of sufficient "authorization" under section 1905: the FOIA itself, $i d$. at 303-04; agency "housekeeping" disclosure regulations, $i d$. at 308-12; and agency disclosure regulations promulgated in the absence of "a nexus between the regulations and some delegation of the requisite legislative authority by Congress," id. at 304.

33. See R. Ehlke, Federal Protection of Trade Secrets and Proprietary. Commercial and Financial Information Obtained by Government Agencies in the Context of EnergyRelated Data (Oct. 13, 1977) (Congressional Research Service No. 77-226A). Ehlke enumerates 68 statutory provisions that in various ways limit disclosure of trade secrets and confidential business information by agencies. Id. at 12,54-101. Most of these provisions in fact simply incorporate either the FOIA or the TSA by reference. See, e.g., 15 U.S.C. \$ 1193 (c) (1976) (Flammable Fabrics Act; incorporating TSA); 15 U.S.C. $\$ 78 x$ (1976) (securities information; incorporating FOIA); 15 U.S.C. \$ 773(b) (1976) (energy information; incorporating both TSA and FOIA).

34. The Chrysler Court refused to determine whether exemption (b)(4) and section 1905 encompassed the same materials, 441 U.S. at 319 n.49, and also declined to decide whether the TSA was an "exempting statute" within the terms of 5 U.S.C. \$ 552(b)(3) (FOIA does not apply to information "specifically exempted from disclosure by statute," with certain conditions), 441 U.S. at 319 n.49. Instead, the case was remanded for a determination as to "whether the contemplated disclosures would violate the prohibition of $\S 1905$." Id. at 319 .

35. Before Chrysler, a number of commentators suggested that, in light of its sketchy legislative history, the TSA should be interpreted narrowly so as to apply only to the limited substantive areas covered by its three predecessor disclosure statutes. See 1978 FOIA REPORT, supra note 1, at 58; Clement, supra note 21, at 613-24; English, supra note 14, at 165-67. The Department of Justice has adopted this construction for future litigation purposes. U.S. Dep't of Justice, Assistant Attorney General's Memorandum, Current and Future Litigation Under Chrysler v. Brown (June 21, 1979), reprinted in 2 Gov'T Disczosure (P-H) I 300,791, at 300,794. Campare Note, Chrysler Corporation v. Brown: Seeking a Formula for Responsible Disclosure Under the FOIA, 29 CATH. U.L. Rev. 159, 179 (1979) (broad reading of TSA undesirable because it could "prohibit disclosure of virtually all businessrelated information") and Note, Reverse FOIA Suits After Chrysler: A New Direction, 48 
TSA is read quite broadly, so as to apply to most if not all of the business information deemed to fall within the (b)(4) exemption, then the amount of business information that could be released by an agency under the FOIA would be severely restricted..$^{36} \mathrm{~A}$ number of courts, relying upon the TSA, have overturned agency decisions to disclose records the release of which had been sanctioned prior to the Chrysler decision. ${ }^{37}$ Other courts, while upholding an agency's decision to disclose, have demanded a considerable showing that the disclosure regulations under review in fact received the necessary congressional blessing. ${ }^{38}$ In addition, a number of agencies have attempted to reduce their own discretion to a minimum by issuing advance determinations, either in the form of rulings or regulations, as to the confidentiality and disclosability of whole categories of documents within their files. ${ }^{39}$ Thus, although the FOIA itself does not limit an agency's disclosure discretion, in recent years courts and agencies have significantly undermined that discretion.

Fourth and finally, if an agency exercises its discretion to disclose

FORDHAM L. REv. 185, 199-202 (1979) (urging narrow interpretation of TSA) with Note, supra note 12, at 290-91 (TSA should be construed identically in scope to exemption (b)(4) to afford significant protection to submitters of confidential information).

36. Although the Court in Chrysler both acknowledged and sanctioned agency disclosure discretion in the context of the FOIA, see 441 U.S. at 294, the Court nonetheless undercut much of that discretion by resurrecting the TSA. If the TSA is read broadly, then before a federal agency could release allegedly sensitive business documents, it would have to demonstrate that its actions were taken in accordance with an explicit legislative mandate designed to further certain regulatory ends-the same standard that governed agency disclosure decisionmaking before the adoption of the FOIA.

37. Compare General Motors Corp. v. Marshall, 1 Gov't Disclosure (P-H) ๆ 80,019 (E.D. Va. Jan. 3, 1980) (EEO manning tables) and Gulf Oil Corp. v. Marshall, 1 Gov'r Disclosure (P-H) ๆ 79,163 (D.D.C. Dec. I1, 1979) (same) with Metropolitan Life Ins. Co. v. Usery, 426 F. Supp. 150, 163-66 (D.D.C. 1976) (allowing access to certain EEO forms on grounds that much of information contained therein was nonconfidential).

38. See, e.g., Parkridge Hosp., Inc. v. Califano, 625 F.2d 719, 724 (6th Cir. 1980) (Medicare Provider Cost reports can be released without violating TSA because HEW regulations satsify Chrysler "nexus" test); St. Mary's Hosp., Inc. v. Harris, 604 F.2d 407, 410 (5th Cir. 1979) (same); Cedars Nursing \& Convalescent Center, Inc. v. Aetna Life \& Cas. Ins. Co., 472 F. Supp. 296,298 (E.D. Pa. 1979) (same).

39. See, e.g., FDA Public Information, 21 C.F.R. $\$ \$ 20.100-119$ (1980) (mandating disclosure or nondisclosure under FOIA of specific categories of records); EPA Public Information, 40 C.F.R. $\S 2.207$ (1980) (providing for class determinations for certain types of business material). See generally 1978 FOIA REPORT, supra note 1, at $40-46$ (discussing agency substantive disclosure rules); 2 Gov'T Disclosure (P-H) ๆT 303,011-402,421 (1980) (collecting relevant federal agency regulations). At least one agency has seized upon the TSA and Chrysler to justify its refusal even to entertain requests for the disclosure of exempt business documents. See Federal Information Tools, Alexandria, Virginia, 3 DOE (CCH) 180,163 , at 80,809-10 (Apr. 30, 1979) (inappropriate, in light of Chrysler and TSA, to consider factor such as "public interest" in making FOIA disclosure decisions; if document falls within (b)(4) exemption, it should never be released). 
information that falls within an exemption but is not covered by the TSA and similar statutes, the agency must still demonstrate to a reviewing court that it did not abuse its discretion. ${ }^{40}$ The courts have not yet explained precisely what would constitute an abuse of discretion in this context. The only standard that can be extracted from the cases is that, in deciding whether or not to release a particular exempt business document, agencies should engage in some sort of balancing test designed to determine whether the public benefit to be realized from disclosure outweighs the risk of injury to the submitter of the information. ${ }^{41}$ This rough balancing process will be examined in more detail below.

To date, these four emerging doctrines have failed to settle the controversy surrounding the disclosure of business records under the FOIA. ${ }^{42}$ The doctrines need both reexamination and revision.

\section{Rethinking the Business Records Controversy}

In essence, the business records dispute stems from the clash of two powerful yet conflicting principles, one favoring the disclosure and the other the nondisclosure of government-held business documents. For the most part, existing legal doctrines attempt to foreclose examination of the conflicts underlying each particular FOIA request. Although this approach may minimize agency effort, it re-

40. Although the Chrysler Court found no private right of action under the TSA for submitters of business documents, 441 U.S. at 316-17, a party having reason to believe its secrets are soon to be made public by a federal agency can seek judicial review under section 10 of the Administrative Procedure Act, 5 U.S.C. $\$ \$ 702,706(2)$ (1976), after it has exhausted its administrative appeals. 441 U.S. at 318; see Schwartz, Administrative Law Cases During 1979, 32 AD. L. REv. 411, 439-40 (1980) (submitter's ability to prevent disclosure not affected despite Chrysler's elimination of reverse-FOIA action, since suits can be brought under APA).

41. See, e.g., Pennzoil Co. v. Federal Power Comm'n, 534 F.2d 627, 631 (5th Cir. 1976) (balancing of public and private interests necessary to avoid abuse of agency disclosure discretion); Doctors Hosp. of Sarasota, Inc. v. Califano, 455 F. Supp. 476, 480-81 (M.D. Fla. 1978) (same); 1965 SENATE REPORT, supra note 7, at 3 (philosophy of full agency disclosure to be balanced in particular cases with important privacy rights); Note, Administrative Disclosure of Private Business Records Under the Freedom of Information Act: An Analysis of Alternative Methods of Review, 28 Syracuse L. Rev. 923, 966-70 (1977) (same).

42. See Lemann, Freedom of Information Act: More Helpful to Lawyers, Wash. Post, June 7, 1980, at A3, col. 1 (use of FOIA to acquire business-related material continues). The federal courts remain deeply immersed in business records litigation. Id. (more than 150 reverse-FOIA-type cases currently pending). See also S. 2397, 96th Cong., 2d Sess., 126 Cong. REc. S2319 (daily ed. Mar. 6, 1980) (proposed amendments to FOIA designed to provide greater protection against disclosure of government-held business information); Notice, Administrative Conference of the United States, Freedom of Information Act; Confidential Business Information, 45 Fed. Reg. 70,033 (1980) (soliciting examples of agency disclosure of exempt (b)(4) material); Stevenson, supra note 18, at 16, col. 1 (discussing recent developments in business records controversy). 
sults in disclosure and nondisclosure decisions that appear misguided when viewed from a broader perspective.

\section{A. The Disclosure and Nondisclosure Principles}

There are important reasons why a great deal of privately generated material in the files of the government should be protected from public exposure. At the very least, a comprehensive disclosure policy might impair the government's access in the future to voluntarily submitted confidential business data. ${ }^{43}$ Furthermore, such disclosures could inflict serious competitive harm upon particular private businesses ${ }^{44}$ conceivably resulting in a violation of the Constitution. ${ }^{45}$ Moreover, the repeated release by the government of businesses' commercial and financial secrets might discourage private incentives to discover, collect, and use commercially valuable information. ${ }^{46}$

43. See National Parks \& Conservation Ass'n v. Morton, 498 F.2d 765, 767 (D.C. Cir. 1974) (if not assured of confidentiality, businesses may refuse to volunteer information, thereby impairing agencies' ability to make intelligent decisions); J. O'ReIlly, supra note 7, $\S 14.08$, at $14-30$ (difficult for government to obtain information from businesses that fear it will be made public). Where businesses are required to submit certain information to the government, however, disclosure will not impair an agency's future access to information. See National Parks \& Conservation Ass'n v. Morton, 498 F.2d 765, 770 (D.C. Cir. 1974).

In response to what is viewed as increasing, reckless government disclosure, a number of businesses recently have taken steps either to prevent federal agencies from receiving certain information, see, e.g., SEC v. Lockheed Aircraft Corp., 404 F. Supp. 651 (D.D.C. 1975) (corporation refused to disclose material because SEC allegedly would not keep it secret); 1977 Senate Hearings, supra note 1, at 7, 8 (testimony of Gerald P. Norton, Deputy General Counsel, FTC) (difficult for FTC to collect information from businesses that fear it inevitably will be disclosed), or to impress upon federal agencies the need for confidential treatment of any documents they submit, see, e.g., Wachtell, Disclosure to Third Parties of Information Filed With Government Agencies: Preventing Disclosure to Third Parties, 34 Bus. Law. 1049, 1057-60 (1979); Ward, Practical Steps for Protecting Confidential Business Information Submitted to the Government, 1 Gov'T Disclosure (P-H) ๆ 7013 (1980).

44. See, e.g., National Parks \& Conservation Ass'n v. Kleppe, 547 F.2d 673, 681-83 (D.C. Cir. 1976) (disclosure of concessioners' financial records might cause them substantial competitive injury); Covington \& Burlington [sic], Washington, D.C., 4 DOE (CCH) I 80,130 (July 25, 1979) (disclosure of crude oil importation forms likely to cause substantial harm to competitive positions of companies involved); J. O'ReILly, supra note 7, $\$$ 14.07-.08 (citing cases).

45. Public disclosure of a business' trade secrets or confidential information might constitute a "taking" under the Fifth Amendment. Wearly v. FTC, 462 F. Supp. 589, 598 (D.N.J. 1978), vacated on other grounds, 616 F.2d 662 (3d Cir. 1980). Most commentators and courts, however, have rejected the taking argument. See McGarity \& Shapiro, supra note 2, at 865-67 (forced disclosure is constitutional as reasonable regulation of commerce); Note, Protecting Confidential Business Information From Federal Agency Disclosure After Chrysler Corp. v. Brown, 80 Colum. L. REv. 109, 129-32 (1980) (questioning Wearly).

46. See Brief Amicus Curiae of the Association for the Advancement of Invention and Innovation at 2-6, Chrysler Corp. v. Brown, 44I U.S. 281 (1979) (disclosure of confidential commercial information is disincentive to future innovation); J. O'REILLX, supra note 7, § 14.14, at 14-55 (same); Posner, The Right of Privacy, 12 GA. L. REv. 393, 404 (1978) (con- 
Equally important reasons, however, can be advanced for making available to the public many business records in the possession of federal agencies. To the greatest extent possible, official conduct should be transparent: government decisionmaking within the federal agencies should be exposed to public scrutiny. ${ }^{47}$ Because government-held business documents are relied upon by the government in its decisionmaking, they should be disclosed. ${ }^{48}$ This decisionmaking transparency is justified in part by a desire to prevent bureaucratic waste and corruption, ${ }^{49}$ in part by a belief that an "open" government is a more "democratic" government, ${ }^{50}$ and in part by a recognition that an informed public is better able to assess not only the adequacy of the government's performance, but also the compliance of businesses with certain important public policies. $^{51}$

Inevitably, however, given the "mixed" character of most of the documents involved, ${ }^{52}$ these two broad objectives conflict in

trary to legislative trend, economic theory requires more protection for private business information than personal information).

47. House Comm. on Government Operations, A Citizen's Guide on How to Use the Freedom of Information Act and the Privacy Act in Requesting Government Documents, H.R. REP. No. 793, 95th Cong., lst Sess. 3 (1977) (openness prevents government corruption); 1966 House REPORT, supra note 6, at 2429 (FOIA designed to ensure availability of government information to interested citizens); 1965 SENATE REPORT, supra note 7 , at 3 (policy of full agency disclosure necessary if agencies are to be responsible to public); Kronman, The Privacy Exemption to the Freedom of Information Act, 9 J. LEGAL STUd. 727, 733-34 (1980) (FOIA used to monitor official conduct).

48. See Brief of Amici Curiae Consumer Federation of America, Women's Equity Action League, Mexican American Legal Defense and Educational Fund, and Women's Legal Defense Fund at 9-12, Chrysler Corp. v. Brown, 441 U.S. 281 (1979) (public fully informed only if it has access to "submitter-generated information to which agency action or inaction relates"); 1978 FOIA REPORT, supra note 1, at 9 (information supplied by businesses reveals how well agencies are regulating industry); $c f$. Koch \& Rubin, supra note 12, at 54 (public should have access to underlying private documents upon which agency decisions are based).

49. See Kronman, supra note 47, at 733; Montgomery, Peters, \& Weinberg, supra note 14, at 10-11 (FOIA openness likely to result in more consistent and equitable agency policies).

50. Ste pp. 401-0ं2 supra.

51. Sec, e.g., 1978 FOIA REPORT, supra note 1, at 10 (FOIA used by those concerned about business compliance with civil rights laws); R. STEvenson, Corporations and INformation: SeCReCY, ACCess, and Disclosure 182-96 (1980) (disclosure of information renders corporations "more accountable for the social consequences of their behavior").

52. See 1978 FOIA REPORT, supra note 1 , at 9 (commercial documents submitted to agencies both "reveal details of business operations" and reflect "functions, operations, and activities of Government"); $c f$. Brief of Amici Curiae Consumer Federation of America, Women's Equity Action League, Mexican American Legal Defense and Educational Fund, and Women's Legal Defense Fund at 9-I 1, Chrysler Corp. v. Brown, 441 U.S. 281 (1979) (information that businesses consider confidential, if disclosed, enables public to examine government's efforts at preventing private sector abuse). 
deciding whether to disclose specific business records. ${ }^{53}$ Information that would be of assistance in evaluating government decisionmaking is precisely the information that could bestow unearned benefit upon one business to the detriment of another. ${ }^{54}$ With only slight variations, the same basic dilemma arises in case after case: a decision in favor of disclosure might dampen private research incentives and reduce the willingness of businesses to provide information to the government; yet a decision not to disclose could interfere both with the public's ability to supervise the policy-related decisions of business and government and with society's desire to avoid duplicative and wasteful information-gathering efforts.

Given this dilemma, unless a decision is made at the outset to sacrifice one principle to the other, a scheme is needed to satisfy the two principles and to reconcile them to the greatest extent possible in each particular case. Existing legal doctrines do not meet this need.

\section{B. The Failure of Existing Legal Doctrines}

Existing legal doctrines have failed to arrive at a satisfactory resolution of the business records disclosure-nondisclosure dilemma. The current rules are tilted heavily in favor of the nondisclosure of business documents; agencies possess too much nondisclosure discretion and insufficient disclosure discretion. Moreover, in those instances in which agencies do decide whether or not to disclose, they employ a procedural framework that is at once nebulous, restrictive, and arbitrary.

53. See O'Reilly, supra note 4, at 1125 (public right to know versus government's need to keep certain information confidential).

54. For example, the public is genuinely concerned with the extent of the energy crisis, the pricing and supply policies of the major energy producers, and the regulatory policies of the Department of Energy. Yet virtually all information collected by the Department consists of detailed-and valuable-price and supply data submitted in confidence by various energy companies. Were the Department to disclose these data, the competitive position of some or all of the companies might be affected. Moreover, the Department could find itself unable to elicit such information in the future-except under subpoena. Sce, e.g., Jones, Day, Reavis \& Pogue, Washington, D.C., 4 DOE (CCH) $\$ 80,146$ (Sept. 7, 1979) (Department of Energy refusal to release data supporting alleged failure of refiners to comply with pricing rules on grounds that disclosure could harm companies competitively and hinder future efforts to obtain such information); 1 Department of Energy Authorization-Fiscal Year 1979: Hearings Before the Subcomm. on Energy and Power of the House Comm. on Interstate and Foreign Commerce, 95th Cong., 2d Sess. 213-16 (1978) (Department of Energy often must promise confidentiality to obtain business information); $c f$. notes $2 \&$ 19 supra (discussing disclosure of EEO manning reports); McGarity \& Shapiro, supra note 2, at 839-57 (discussing confidentiality of drug, pesticide, and chemical test data). 


\section{Business Records}

\section{Discretionary Nondisclosure}

By permitting agencies automatically to reject requests for the release of exempt business documents, existing legal doctrines invite irrationality and bias into the administration of the (b)(4) exemption. If an agency automatically exercises its discretion to prevent disclosure, it will deny FOIA requests for exempt documents without even considering the merits of those requests. The possibility of disclosure thus may be rejected irrationally at the outset, even when further inquiry would reveal that the release of the document would either greatly benefit the public or only moderately injure the submitter. ${ }^{55}$ In effect, because an agency need not disclose or even consider disclosing exempt business records, existing rules tolerate a complete sacrifice of the disclosure to the nondisclosure principle. $^{56}$

By permitting such absolute nondisclosure discretion, moreover, existing rules also are unable to uncover and respond to the potential problem of agency bias or "capture." 57 At present, an agency can decline to consider the release of an exempt business record for any of a number of suspect but unexpressed reasons ${ }^{58}$ without violating existing standards or fearing public exposure. Although an agency's nondisclosure decision presumably is motivated by a concern about the possible effects of releasing commercial secrets, ${ }^{59}$ there is currently no way to ascertain whether a particular

55. Sé J. O'REILLY, supra note $7, \$ 9.06$, at 9-16 (agencies permitted to withhold exempt records "without having to rationalize why the exemption is not being waived" even if records pertain to "innocuous matters"); Saloschin \& Pitt, supra note 18, at 1067 (statement of Robert L. Saloschin, Chairman, Freedom of Information Committee, U.S. Dep't of Justice) (agency permitted to withhold information having " 5 per cent chance of doing $\$ 500$ worth of damage to a business" even if disclosure would save " $\$ 950$ million, plus 44,000 lives").

56. Agencies have made discretionary releases of (b)(4) information on only "rare" occasions. See Saloschin \& Pitt, supra note 18, at 1068 (statement of Robert L. Saloschin, Chairman, Freedom of Information Committee, U.S. Dep't of Justice).

57. An administrative agency is "captured" when it acts primarily out of regard for the interests of those it was meant to regulate, at the expense of the public interest or of the agency's congressional mandate. See F. Rourke, Bureaucracy, Politics, and Public PolICY 51-56 (2d ed. 1976) (discussing "captive agency" concept); Stewart, The Reformation of American Administrative Law, 88 HARv. L. REv. 1667, 1684-87 (1975) (same); cf. Engel, Introduction: Information Disclosure Policies and Practices of Federal Administrative Agencies, 68 Nw. U.L. REv. 184, 212 (1973) (agencies often refuse to disclose information in order to protect businesses they regulate from public scrutiny); McGarity \& Shapiro, supra note 2, at 843 (nondisclosure of health and safety testing information may foster pro-industry bias in agency decisionmaking).

58. Such suspect reasons for nondisclosure could include outright prejudice in favor of certain business interests, an attempt to cover up administrative favoritism, an undue deference to business submitters, or a desire not to expose business impropriety.

59. See Saloschin \& Pitt, supra note 18, at 1064 (statement of Robert L. Saloschin, 
FOIA request was rejected because of an unexpressed desire to sacrifice the public good to a favored private interest.

Traditional administrative law doctrines guard against the potential for irrationality and bias by requiring that, when making decisions, agencies follow written standards ${ }^{60}$ weigh all potentially relevant factors, ${ }^{61}$ and make a record setting forth the reasons for any conclusion. ${ }^{62}$ Such procedural protections are absent in the business records context, however, because the agency's discretion not to disclose is absolute. This arrangement undoubtedly avoids adding to the already high administrative burdens shouldered by agencies under the FOIA, ${ }^{63}$ but such administrative efficiency is purchased at an inordinately high cost.

\section{Mandatory Nondisclosure}

Before an agency can disclose an exempt business record pursuant to an FOIA request, it must ensure that release of the desired record would violate neither the Trade Secrets Act nor any other similar statute. These restrictions often erect a virtually insurmountable bar to the disclosure of government-held, businessrelated materials. This subversion of the disclosure principle would not be objectionable if Congress deliberately enacted each nondisclosure statute after a careful determination that the particular business document ought not to be made available to the public. ${ }^{64}$

Chairman, Freedom of Information Committee, U.S. Dep't of Justice) (agencies refuse to disclose exempt information to avoid inflicting competitive harm upon companies); Letter from Griffin B. Bell to Heads of all Federal Departments and Agencies, supra note 29 (listing four criteria for deciding whether to release FOIA-exempt documents).

60. See, e.g., Morton v. Ruiz, 415 U.S. 199, 231 (1974) (agency failed to formulate and publish policy rules to guide its discretion); White v. Roughton, 530 F.2d 750, 754 (7th Cir. 1976) (administrator failed to establish written standards and regulations; such "unfettered discretion" clearly violated due process).

61. See, e.g., Citizens to Preserve Overton Park, Inc. v. Volpe, 401 U.S. 402, 416 (1971) (courts must ensure that agencies take into account all relevant factors); Air Line Pilots Ass'n, Int'l v. CAB, 475 F.2d 900, 905 (D.C. Cir. 1973) (agency cannot refuse to consider possibly relevant factor when balancing to determine public interest).

62. See, e.g., Burlington Truck Lines, Inc. v. United States, 371 U.S. 156, 167 (1962) (exercise of agency discretion invalid in absence of findings, analysis, or some indication of basis for decision); Environmental Defense Fund, Inc. v. Ruckelshaus, 439 F.2d 584, 597-98 (D.C. Cir. 1971) (discretionary decisions should be supported with findings of fact and reasoned opinions).

63. See 1977 Senate Hearings, supra note 1, at 3, 4 (statement of Sherwin Gardner, Deputy Commissioner, FDA) (FDA shifted resources and personnel from policy programs to handle crush of FOIA requests); U.S. DeP'T OF Justice, FOIA UPDATE, Spring 1980, at 2 (cost of administering FOIA at least $\$ 47.8$ million in 1978 ); Lemann, supra note 42 , at A3 (describing actions needed to answer just one FOIA request).

64. See, e.g., 26 U.S.C. $\$ 6103(\mathrm{a})$, (e)(1)(D) (1976 \& Supp. III 1979) (providing for confidentiality of corporate tax returns with specified exceptions). A number of commenta- 
Few nondisclosure statutes, however, are the product of such a detailed and specific determination; ${ }^{65}$ most (particularly the TSA) arose in different contexts, ${ }^{66}$ speak in broad, generalized terms, ${ }^{67}$ and contain no accompanying explanation of their applicability. ${ }^{68}$

Problems that arise in the business records context are particularly ill-suited for resolution by broad, legislatively imposed mandates. FOIA requests for business documents involve a wide variety of circumstances and conditions ${ }^{\mathbf{6 9}}$ and are usually unique and non-

tors have suggested that Congress proceed in precisely such a manner in order to resolve many of the existing areas of contention in the business records context. See, e.g., Role of Giant Corporations: Hearings Before the Subcomm. on Monopoly of the Senate Select Comm. on Small Business, 92 Cong., Ist Sess. 1046, 1056 (1971) (testimony of Ralph Nader) (Congress should enumerate types of business information deserving confidential treatment) [hereinafter cited as 1971 Senate Hearings]; Koch \& Rubin, supra note 12, at 54 (Congress should narrow scope of private documents subject to disclosure under FOIA and make such disclosure automatic): Note, supra note 45, at 132-33 (Congress should prohibit FOIA disclosure of trade secrets and consider prohibiting FOIA disclosure of other business information).

65. See R. Ehlke, supra note 33, at 13 (cursory review of nondisclosure statutes demonstrates "ad hoc and haphazard" development of federal confidentiality protection).

66. Some nondisclosure statutes address concerns other than that of protecting business information. For example, Congress has required that tax returns, 26 U.S.C. $\$ 6103(a)$ (1976), and census data, 13 U.S.C. $\$ 9$ (1976), remain confidential, primarily in order to encourage voluntary compliance with tax and census laws rather than to protect business privacy interests.

Most nondisclosure statutes do not incorporate broader objectives, however, and serve only to bar certain business documents from being released. See note 33 supra. Because many of these statutes were enacted before the rise of the business records controversy and often predate the FOIA, it is unclear precisely how they interact with the FOIA. When Congress enacted the FOIA, it included an exemption requiring nondisclosure of information "specifically exempted from disclosure by statute." 5 U.S.C. \$ 552(b)(3) (1976). The House report, in fact, spoke of "nearly 100 statutes . . . which restrict public access to specific Government records" that "would not be modified" by the FOIA. 1966 HousE REPORT, supra note 6 , at 2427 . These 100 statutes were never enumerated, however, and the evidence suggests that Congress was only vaguely aware of what information legally could be disclosed at the time it approved the FOIA. See J. O'ReILLY, supra note 7, $\$ 13.03$, at 13-5 to 13-6.

To date, Congress has failed to integrate these nondisclosure statutes with the FOIA. Courts have concluded that release of business-related data was barred under subsection (b)(3) of the FOIA in only two contexts other than the tax and census settings: patent applications, 35 U.S.C. $\$ 122$ (1976); see, e.g., Lee Pharmaceuticals v. Kreps, 577 F.2d 610 (9th Cir. 1978), cert. denied, 439 U.S. 1073 (1979), and Consumer Product Safety Commission material, 15 U.S.C. $\$ 2055$ (b)(1) (1976); see, e.g., Consumer Product Safety Comm'n v. GTE Sylvania, Inc., 100 S. Ct. 2051 (1980).

67. See, e.g., 15 U.S.C. $\$ 176 a$ (1976) (Bureau of Foreign and Domestic Commerce may not release "statistical information" furnished to it "in confidence . . . by individuals, corporations, and firms"). Many nondisclosure statutes parallel or refer to the TSA, see note 33 supra, and the language of the TSA is quite sweeping.

68. Se' 1 K. Davis, Administrative Law Treatise $\$ 5.31$ (2d ed. 1978 \& Supp. 1980) (discussing problems of interpreting TSA and other nondisclosure statutes); Campbell, $s u$ pra note 21 , at $143-56$ (same).

69. See 1978 FOIA Report, supra note 1, at 9-11 (varied examples of attempts to use 
recurring. ${ }^{70}$ Evaluating such requests often requires detailed, factdependent inquiries. ${ }^{71}$ Such characteristics suggest that FOIA business records matters are better addressed at the more flexible administrative level rather than by legislation. ${ }^{72}$

The disadvantages that accompany a legislative attempt to draw hard and fast disclosure lines are nowhere more evident than in the Trade Secrets Act itself. As interpreted by the Supreme Court, in the absence of sufficient legal authorization, the TSA apparently would bar disclosure by the government of any trade secrets or confidential statistical data even if (1) such material already is available to the submitter's competitors; ${ }^{73}$ (2) the material could be released only to certain parties or in a somewhat altered form without harming the submitter ${ }^{74}$ or (3) disclosure would benefit the public or the requester much more than it would injure the submitter. ${ }^{75}$ The statute demonstrates how difficult it is to deal with the

FOIA to obtain business records); Campbell, supra note 21, at $107 \mathrm{n} .28$ (citing cases involving many different types of documents); Note, supra note 2 , at $339 \mathrm{n} .3$ (same).

70. Some documents are requested more than once; in those cases an agency need not redetermine its initial disclosure decision, see J. O'Reilly, supra note $7, \S 9.07$, at $9-19$ to 9-21.

71. See National Parks \& Conservation Ass'n v. Morton, 498 F.2d 765, 770 (D.C. Cir. 1974) (agency must determine in each case whether disclosure would cause substantial harm to submitter); ICF, Inc., Washington, D.C., 3 DOE (CCH) I 80,147 (Mar. 14, 1979) (quoting Policy Letter No. 78-3, Office of Federal Procurement Policy of the Office of Management and Budget, that agencies must examine individually the facts in each case before making disclosure decision); GAO FOIA REFORT, supra note 14, at 39 (disposition of one FOIA request involved review of 400,000 documents).

72. See generally $1 \mathrm{~K}$. DAvis, supra note 68 , $\$ 2.12$, at 112 (administrative discretion more desirable than legislative rulemaking for problems that "cannot be governed by rules or even by meaningful standards because no one knows how to write the rules or standards"); L. JAFFe, Judicial Control of AdMinistrative Action 35-36 (1965) (legislative power should be delegated to agencies "where the relations to be regulated are highly technical or where their regulation requires a course of continuous decision"); $c f$. Stewart, supra note 57, at 1695 (detailed legislative policy direction to agencies often neither feasible nor desirable).

73. Some commercially valuable information is released freely by businesses either to other firms within a particular industry or to the public at large. See 1971 Senate Hearings, supra note 64, at 1046, 1072 (statement of Ralph Nader) ("confidential" energy information circulated within oil and gas industries); Kitch, The Law and Economics of Rights in Valuable Information, 9 J. LEGAL STUD. 683, 710 (1980) (businesses "actively disseminate" valuable information about themselves).

74. See pp. 418-19, 429 infra (discussing selective and sanitized disclosure of FOIAexempt business documents).

75. In Hospital Affiliates Int'l, Inc. v. Califano, 1 Gov't Disclosure (P-H) I 79,152 (N.D. Ill. Sept. 28, 1979), HEW disclosure regulations were found insufficient to satisfy the TSA's "authorized by law" standard, and consequently Medicare Provider Cost reports were not released under the FOIA. No consideration was given to factors discussed in a similar case, Parkridge Hosp., Inc. v. Califano, 625 F.2d 719, 724-25 (6th Cir. 1980), which recognized that $\mathrm{HEW}$ and the courts have a "heavy burden" in maintaining the integrity of the Medicare system, that hospitals that object to disclosure of their reports need not ac- 
business records controversy through legislative prescription.

\section{Exercising Disclosure Discretion}

If an agency decides that release of an exempt business document would not violate the TSA, it may then decide whether to make a discretionary disclosure of that document under the FOIA. No precise formulation of the factors that agencies are to take into account in exercising their disclosure discretion has been agreed upon. Commentators simply have suggested that an agency weigh the "public benefit" to be derived from disclosure of a (b)(4) record against the "risk of injury" to the submitter of the requested material. $^{76}$ The few courts that have addressed the question generally have required the agency to show that it found disclosure of a particular document to be "in the public interest," and thus did not "abuse its discretion."77

Existing legal rules governing the discretionary disclosure process are not only unclear but also unduly restrictive, at both the input and the output stages. Existing rules introduce only a limited number of factors into the balancing process. In making discretionary disclosure decisions, agencies and courts focus exclusively on whether the release of a particular document would result in either great benefit to the public or great injury to the submitter. Other potentially relevant matters, such as how the requested material is to be used, by whom, and for what purposes, are ignored. ${ }^{78}$ As a result, an agency may honor an FOIA request for exempt business

cept Medicare reimbursements in the first place, and that any hospital can offset any competitive disadvantage resulting from disclosure by seeking disclosure of its competitors' reports.

76. See, e.g., Clement, supra note 21, at 640; Gavin, Newkirk, \& Saloschin, A Short Guide to the Freedom of Information Act, in GovernMENT INFORMATION: FREEDOM OF INFORMATION Act, Sunshine Act, Privacy Act 65, 99-100 (A. Levenson \& H. Pitt eds. 1978); Note, supra note 41 , at 966 .

77. See Charles River Park “A”, Inc. v. HUD, 519 F.2d 935, 943 (D.C. Cir. 1975) (interest of public in accurate tax assessment balanced against submitter's confidentiality interest to determine whether agency would abuse its discretion by disclosing requested information); note 41 supra (citing cases describing balancing).

78. Most courts and commentators have concluded that it would be inconsistent with the language and the spirit of the FOIA for agencies to consider factors other than the public interest and the submitter's interests when making disclosure decisions. See, e.g., NLRB v. Sears, Roebuck \& Co., 421 U.S. 132, 143 n.10 (1975) (requester's rights under FOIA neither increased nor decreased by requester's interest in disclosure); Soucie v. David, 448 F.2d 1067, 1077 (D.C. Cir. 197I) (FOIA precludes consideration of interests of requester); City of Concord v. Ambrose, 333 F. Supp. 958, 959 (N.D. Cal. 1971) (requester's contentions that it had "need to know" and that its interests were identical to those of agency irrelevant in FOIA context); 1978 FOLA REPORT, supra note 1, at 23 (inquiries concerning purpose of requester are "costly, time-consuming, subjective, and irrelevant"); $1 \mathrm{~K}$. DAvis, supra note $68, \S 5.6$, at 320 (same). 
records even though a closer examination might expose the requester's motivation to be frivolous or suspect; similarly, it may deny an FOIA request even though a closer examination might reveal that significant costs would be suffered by the requester as the result of a nondisclosure decision. ${ }^{79}$

At the output level, existing legal rules unduly limit an agency's discretion with respect to the form an attempted disclosure could take. Under current legal interpretations, once an agency has released a particular record pursuant to an FOIA request, that record is available to all the world for all time: the agency can neither prevent the requester from disseminating the document to others ${ }^{80}$ nor deny a later request for the same document by a different party. ${ }^{81}$ The agency must assume that any document disclosed under the FOIA will eventually and inevitably find its way into the possession of the submitter's competitors. ${ }^{82}$ This discourages the discretionary release of exempt documents. Further, agencies have been reluctant to experiment with various sanitized disclosure schemes, under which exempt records might be released in a form that makes it impossible to discover either the identity of the submitter or any of its commercially valuable secrets. ${ }^{83}$ Similarly, in the

79. See Koch \& Rubin, supra note 12, at 25 (weakness of FOIA is that "it focuses on types of documents rather than on specific needs of participants .... [A] person may have access to masses of government documents regardless of the damage it may do to the decisionmaking process, but may not have access to exempt documents even if great need or substantial impact can be shown.")

80. See Null \& Null, Garden City, New York, 3 DOE (CCH) I 80,154 (Apr. 4, 1979) (agencies, unlike courts, cannot issue protective orders to prevent dissemination of confidential information); 1978 FOIA REPORT, supra note 1, at 23 n.62 (agencies have no authority to restrict requester's use of FOIA information); $c f$. Ditlow v. Shultz, 517 F.2d 166, 171 \& n.21 (D.C. Cir. 1975) (criticizing "use-specified release" of FOIA documents); Disabled Officer's Ass'n v. Rumsfeld, 428 F. Supp. 454, 456 n.3 (D.D.C. I977) (same); Clement, supra note 21, at 643 (same).

81. See City of Concord v. Ambrose, 333 F. Supp. 958, 959 (N.D. Cal. 1971); J. O'ReILly, supra note $7, \$ 9.07$, at $9-18$ (would constitute abuse of discretion for agency to favor one requester over another). But see U.S. DEP'T of Justice, FOIA UPDATE, Summer 1980, at 4-5 (advising agencies that "discretionary access to a particular person" does not necessarily mean "that access must be granted to all persons").

82. See Clement, supra note 21 , at 643 (agencies should assess competitive harm to submitters in light of assumption that "competitors will gain access" to disclosed information).

83. See Weinberg, Protecting Confidential Business Information: The Paper Industry's "Third Party Arrangement" With EPA, in 1 Gov'T Disclosure (P-H) I 7011, at 7012 (1979) (describing scheme whereby certain businesses submit financial information to an independent accounting firm, which forwards data to EPA in tabular form; the agreement keeps " 'raw' confidential business information out of the possession of EPA . . . and thus out of the possession of competitors and the public," yet allows EPA (and the public) "reasonable access to information"). The FOIA mandates that "[a]ny reasonably segregable portion of a record" be released after "deletion" of exempt portions. 5 U.S.C. $\$$ 552(b) (1976). This provision has been used merely as authority to separate exempt from 
absence of clear statutory or precedential authority, agencies have made no effort to determine whether additional disclosure of exempt documents might be permissible if the requester agreed to compensate the submitter for any competitive advantage gained at the latter's expense. ${ }^{84}$

In sum, a more coherent approach to the disclosure process would attempt to evaluate, for each particular FOIA request for an exempt business document, all of the relevant public and private costs and benefits that would accompany disclosure. A more coherent approach also would authorize agencies to release business documents to one party but not to another, to one party in exchange for a promise of confidentiality, or to any party in a form that makes it impossible for that party to profit at the competitive expense of the submitter.

\section{Addressing the Business Records Controversy}

Existing legal doctrines have been unable satisfactorily to apply the conflicting principles of disclosure and nondisclosure to particular cases. The statutes, regulations, and procedures that govern FOIA disclosure decisions with respect to business records should be revised to provide a more rational approach to the discretionary disclosure process, with greater disclosure discretion and less nondisclosure discretion.

\section{A. Two Procedural Models}

The discovery of business documents in civil litigation and the disclosure of personnel and medical files under the FOIA offer guidance for application of the principles of disclosure and nondisclosure in the business records setting. A framework for

nonexempt portions of a document, however, and not as authority to release exempt portions in a sanitized form.

84. See Note, supra note 2 , at 356-67 (outlining proposal whereby successful FOIA requesters of confidential business information would compensate submitters for loss suffered as result of disclosure). A compensated disclosure scheme has been adopted by Congress for use under both the Federal Insecticide, Fungicide, and Rodenticide Act (FIFRA), 7 U.S.C. $\$ 136$ a(c)(1)(D) (Supp. III 1979), and the Toxic Substances Control Act (TSCA), 15 U.S.C. $\$ \$ 2601-2629$ (1976 \& Supp. III 1979). The TSCA requires manufacturers of toxic substances to make health and safety test data public, 15 U.S.C. $\$ 2613$ (b) (1976), but provides that if one manufacturer, in order to obtain an exemption from the Act's testing requirements, relies upon data previously made public by another manufacturer, then unless the two manufacturers "agree on the amount and method of reimbursement," the EPA "shall order the person granted the exemption to provide fair and equitable reimbursement . . . to the person who previously submitted such test data," 15 U.S.C. \$ 2603(c)(3)(A) (1976). See McGarity \& Shapiro, supra note 2, at 874-82 (discussing compensated disclosure provisions of FIFRA and TSCA). 
dealing with requests for confidential business information under the FOIA can be developed by examining the procedures employed in these two contexts.

\section{The Civil Discovery Model}

Requests for discovery of trade secrets and confidential business information arise frequently under Rule 26 of the Federal Rules of Civil Procedure. ${ }^{85}$ In ruling upon such discovery requests, the courts face the same two principles that conflict in the business records context. On the one hand, there are compelling reasons why commercial documents should be discoverable in a civil proceeding, even in a case involving two competitors. Often, the desired confidential business records constitute the evidentiary heart of a lawsuit, ${ }^{86}$ so that many important civil actions could not be maintained if a special privilege existed for commercially sensitive material. Moreover, such a privilege would violate traditional notions that discovery should be liberal and wide ranging. ${ }^{87}$ On the other hand, courts are loath to allow one party to obtain a competitive advantage at the expense of another as a collateral consequence of the discovery process. ${ }^{88}$

Rule 26 vests the decision as to whether or not a particular trade secret or confidential record is discoverable in the discretion of the trial judge. ${ }^{89}$ In exercising that discretion, a judge generally exam-

85. "Parties may obtain discovery regarding any matter, not privileged, which is relevant to the subject matter involved in the pending action . . ." FED. R. Crv. P. 26(b)(1). See generally R. Milgrim, Trade Secrets $\$ 7.06$ (1980); 4 Moore's Federal Practice fif 26.60[4], 26.75 (2d ed. 1979); 8 C. Wright \& A. Miller, Federal Practice and ProceDURE $\$ \& 2020,2035-44$ (1970 \& Supp. 1979).

86. See, e.g., Service Liquor Distrib. v. Calvert Distillers Corp., 16 F.R.D. 507, 509 (S.D.N.Y. 1954) (competitor's business records "precisely the source of the most relevant evidence").

87. See Hickman v. Taylor, 329 U.S. 495,507 (1947) (discovery rules to be accorded "broad and liberal treatment"): Advisory Comm. Note, 5 F.R.D. 433, 454 (1946) (discovery to involve "broad search for facts" and inquiry into "matters in themselves inadmissible as evidence").

88. See Dore, Confidentiality Orders-The Proper Role of the Courts in Providing Confidential Treatment for Information Disclosed Through the Pre-Trial Discovery Process, 14 NEw ENG. L. Rev. 1, 8 n.45 (1978); Senio, Protection of Trade Secrets in Litigation: Guarding Against the "Infinite Mischief" of Unrestricted Disclosure, in R. MILGRIM, supra note 85, at I1-1.

89. See A.H. Robins Co. v. Fadely, 299 F.2d 557, 562 (5th Cir. 1962); 8 C. Wright \& A. Miller, supra note 85, $\$ 2043$, at 305 (citing cases). Appellate courts, however, occasionally will correct a trial judge's abuse of discretion in the business documents discovery context. See, e.g., Natta v. Zletz, 405 F.2d 99, 100 (7th Cir. 1968), cert. denied, 395 U.S. 909 (1969) (overturning "unduly restrictive" discovery order); Hartley Pen Co. v. United States Dist. Court, 287 F.2d 324, 331 (9th Cir. 1961) (mandamus issued to overturn sweeping discovery order).

The assertion in Rule 26 that parties may obtain discovery of relevant matters "not privileged" has never been construed so as automatically to exclude confidential business infor- 


\section{Business Records}

ines a number of factors, including the contents of the requested document, ${ }^{90}$ the status of the party seeking discovery, ${ }^{91}$ the party's need for the document in order to make its case, ${ }^{92}$ and the harm that would result to the party against whom discovery is being sought if the document were released. ${ }^{93}$ As a general rule, business records are held discoverable upon a party's showing that the desired records are "relevant or may lead to relevant matters" in a particular civil case. ${ }^{94}$

Despite this liberal approach to disclosure, however, courts have not neglected nondisclosure. A court will not hesitate to deny a trade secret discovery request if no legitimate purpose for the request has been advanced. ${ }^{95}$ Further, if convinced that disclosure would result in a "clearly defined, serious injury" to the person or business whose records are involved, ${ }^{96}$ a court will issue a protec-

mation. See Federal Open Market Comm. v. Merrill, 443 U.S. 340, 362 (1979) (no absolute privilege for confidential business information); Covey Oil Co. v. Continental Oil Co., 340 F.2d 993, 999 (10th Cir.), cert. denied, 380 U.S. 964 (1965) (same); Advisory Comm. Note, 48 F.R.D. 487, 505 (1970) (courts have afforded business secrets "limited protection," weighing in each case "claim to privacy" against "need for disclosure").

90. See, e.g., Monaco v. Miracle Adhesives Corp., 27 Fed. R. Serv. 2d 1401, 1402 (E.D. $\mathrm{Pa} .1979$ ) (court inquires into whether information sought to be protected is confidential or trade secret); United States v. IBM Corp., 67 F.R.D. 40, 47 (S.D.N.Y. 1975) (same).

91. See, e.g., Everco Indus., Inc. v. O.E.M. Prods. Co., 362 F. Supp. 204, 206 (N.D. Ill. 1973) (competitor may not discover confidential documents without sufficient cause); Triangle Mfg. Co. v. Paramount Bag Mfg. Co., 35 F.R.D. 540, 543 (E.D.N.Y. 1964) (court reluctant to make party's commercial secrets available to competitor); 4 MOORE's FEDERAL Practice, supra note 85, $\{$ 26.60[4], at 26-243 n.2 (some cases have emphasized "absence of business competition" between litigants as basis for rejecting confidentiality claim).

92. See, e.g., Hartley Pen Co. v. United States Dist. Court, 287 F.2d 324, 331 (9th Cir. 1961) (documents not "relevant and necessary" to matter at issue cannot be discovered); Stanley Works v. Haeger Potteries, Inc., 35 F.R.D. 551, 555 (N.D. Ill. 1964) (same); Service Liquor Distrib. v. Calvert Distillers Corp., 16 F.R.D. 507, 509 (S.D.N.Y. 1954) (discovery permitted because competitor's records constituted "most relevant evidence").

93. See, e.g., United States v. United Fruit Co., 410 F.2d 553, 556-57 (5th Cir.), cert. denied, 396 U.S. 820 (1969) (discovery denied upon showing by party that it would be harmed were information disclosed); Essex Wire Corp. v. Eastern Elec. Sales Co., 48 F.R.D. 308, 311-12 (E.D. Pa. 1969) (party opposing discovery failed to demonstrate it would be harmed by disclosure).

94. Natta v. Zletz, 405 F.2d 99, 101 (7th Cir. 1968), cert. denied, 395 U.S. 909 (1969) (allowing discovery of "valuable trade secrets" which lower court labeled irrelevant and undiscoverable). See generally R. MILGRIM, supra note 85, \$ 7.06[1][b] (citing cases discussing "relevancy"). Because courts have declined to recognize an absolute privilege for confidential business information, discovery routinely has been allowed with respect to a multitude of sensitive commercial documents, including secret sales information, product ingredient summaries, manufacturing process descriptions, customer lists, research data, and production cost information. See 4 Moore's Federal Practice, supra note 85, I 26.60[4] (citing cases).

95. See, e.g., Hartley Pen Co. v. United States Dist. Court, 287 F.2d 324, 331 (9th Cir. 1961) (defendant failed to demonstrate that documents sought were "relevant and necessary to its proper defense of the main action"); Struthers Scientific \& Int'l Corp. v. General Foods Corp., 50 F.R.D. 184, 186 (D. Del. 1970) (same).

96. Monaco v. Miracle Adhesives Corp., 27 Fed. R. Serv. 2d 140I, 1402 (E.D. Pa. 1979) 
tive order under Rule 26(c). ${ }^{97}$ Protective orders, though varying in form, generally restrict either a party's access to $^{98}$ or its collateral use of ${ }^{99}$ commercially valuable information made available during civil discovery. Through the creative employment of protective orders, courts attempt to reconcile demands for wide-ranging discovery with claims for business confidentiality. ${ }^{100}$

The procedural techniques that courts have used to address the competing arguments surrounding the discovery of confidential commercial information can be applied to the rules governing the disclosure of business records under the FOIA. ${ }^{101}$ Agencies, like

(following United States v. IBM Corp., 67 F.R.D. 40, 46 (S.D.N.Y. 1975)). No protective order was issued in Monaco because the party resisting discovery could not make such a showing.

97. Upon motion by a party or by the person from whom discovery is sought, and for good cause shown, the court .. . may make any order which justice requires to protect a party or person from annoyance, embarrassment, oppression, or undue burden or expense, including . . (7) that a trade secret or other confidential research, development, or commercial information not be disclosed or be disclosed only in a designated way ....

FED. R. CIV. P. 26(c).

98. See, e.g., Covey Oil Co. v. Continental Oil Co., 340 F.2d 993, 999 (10th Cir.), cert. denied, 380 U.S. 964 (1965) (documents made available only to counsel and independent accountants); Gentron Corp. v. H.C. Johnson Agencies, Inc., 79 F.R.D. 415, 419 (E.D. Wis. 1978) (disclosure only to party's attorneys, employees, and experts); Tosa ChryslerPlymouth, Inc. v. Chrysler Motors Corp., 55 F.R.D. 41, 43 (E.D. Wis. 1972) (disclosure only to "those persons, not competitors of the defendant, whose aid is necessary in the preparation of the plaintiff's case").

99. See, e.g., Covey Oil Co. v. Continental Oil Co., 340 F.2d 993, 999 (10th Cir.), cert. denied, 380 U.S. 964 (1965) (documents made available only for "purposes of the case" and not competitive purposes); Alliance to End Repression v. Rochford, 75 F.R.D. 43I, 434 (N.D. Ill. 1976) (public disclosure prohibited); Maritime Cinema Serv. Corp. v. Movies en Route, Inc., 60 F.R.D. 587, 592 (S.D.N.Y. 1973) (documents to be returned to court when no longer needed for trial preparation); Hunter v. International Sys. \& Controls Corp., 51 F.R.D. 251, 262 (W.D. Mo. 1970) (documents made available pursuant to already existing contract that they not be disclosed to anyone else).

100. Other variations on the protective order theme are possible. See Natural Resources Defense Council, Inc. v. Grant, 355 F. Supp. 280, 284-85 (E.D.N.C. 1973) (discovery permitted after deletion of "names, addresses, and income data of the persons providing the information"); Shawmut, Inc. v. American Viscose Corp., 11 F.R.D. 562, 566 (S.D.N.Y. 1951) (party ordered to disclose names of only fifty customers).

101. The business records situation differs in two respects from the civil discovery process. First, unlike the FOIA context where information can be requested without a showing of need, before a party can employ civil discovery tools it must present a claim upon which relief can be granted. FED. R. Crv. P. 8(a). That required showing, however, has not proved very burdensome under modern rules of pleading, see 2A MoorE's FEDeral Practice If 8.13 (2d ed. 1980), and courts are reluctant to dismiss an action for failure to state a claim before the complaining party has had an opportunity to use "the machinery of discovery . . . to ferret out facts and delineate issues," Mitchell v. E-Z Way Towers, Inc., 269 F.2d 126, $130-31$ (5th Cir. 1959). Some frivolous suits undoubtedly are dismissed at the complaint stage before discovery can be obtained, and no such procedure is possible under the FOIA. Nevertheless, even though frivolous FOIA requests for business documents cannot be rejected at the outset, they can be entertained, balanced, and 
courts operating under Rule 26, should take all potentially relevant factors into account, including the interests and the needs of the requester, in making FOIA disclosure decisions regarding business records. In addition, agencies should experiment with protective orders, ${ }^{102}$ so that a deserving FOIA request need not be denied simply because of fear that commercially valuable information might become available to a submitter's competitors.

\section{The FOIA Personal Privacy Model}

\section{An intricate balancing scheme has been developed to reconcile the competing claims of disclosure and nondisclosure in a second}

denied with little effort and with the same result as under civil discovery-the document is not made available to an undeserving requester. Moreover, any presumption in favor of disclosure that might exist in the civil discovery setting as a result of the necessity for an initial showing of a valid claim need not be applied in the FOIA context, where such a showing is not required.

Second, it might be argued that the civil discovery model and the FOIA context differ because federal agencies, unlike judges, will not always be able to act impartially and without self-interest in making disclosure decisions. The potential for agency bias, however, exists to an even greater extent under current legal arrangements, because agencies possess absolute nondisclosure discretion. This Note seeks to improve upon existing arrangements by requiring agencies to evaluate rationally in each case all relevant facts and interests. Although the potential for agency bias will not disappear with the adoption of a more open and rational procedural system, agencies are expected in other contexts to act impartially in accordance with prescribed procedural rules, even in situations in which it might seem inherently difficult for them to do so. See Attorney General's Comm. on Administrative Procedure, Administrative Procedure in Government Agencies, S. Doc. No. 8, 77th Cong., 1st Sess. 55-59 (1941) (agencies vested with both policymaking and adjudicatory responsibilities, despite resulting potential for intra-agency conflict). Finally, judicial review is available to challenge an agency's abuse of its disclosure discretion. $C f$. L. JAFFE, supra note 72 , at 325 (even though agency is primarily responsible for objectives of good administration, judicial review needed to check administrative activity).

102. In Charles River Park "A", Inc. v. HUD, 519 F.2d 935, 943 (D.C. Cir. 1975), the court suggested that exempt documents could be released "on the condition that (the requester] keep them confidential." The court did not address the enforcement question, however, and some commentators have suggested that agencies lack authority to punish for violation of the terms of any restricted-use agreement. See Clement, supra note 21, at 643; Note, Would Macy's Tell Gimbel's: Government-Controlled Business Information and the Freedom of Information Act, Forwards \& Backwards, 6 LoY. CHI. L.J. 594, 606 n.83 (1975).

Without additional statutory authority, agencies may be able to enforce protective-ordertype agreements simply by stressing to the requester that the information released to it is not to be disclosed to another party. See Murphy v. Department of Army, 613 F.2d 1151, 1158 (D.C. Cir. 1979); Getman v. NLRB, 450 F.2d 670, 677 n.24 (D.C. Cir. 1971). Agencies may be able to exert a number of extralegal pressures to enforce such restrictions (for example, an agency might announce that violators of confidentiality agreements will receive adverse publicity and will be denied access to exempt documents in the future). Moreover, in making its disclosure decision in the first place, an agency could take into account the probability that a particular requester would abide by a confidentiality promise. Agencies also may choose to reject a request for exempt business records, encourage the requester to bring an FOIA suit in district court, and then enter into a stipulated, courtenforceable protective order restricting the requester's ability to disseminate any documents that the requester receives. 
context. Subsection 552(b)(6) of the FOIA exempts from the Act's mandatory disclosure requirements "personnel and medical files ... the disclosure of which would constitute a clearly unwarranted invasion of personal privacy." "03 The interests at stake in the (b)(6) personal privacy setting are quite similar to those implicated by the (b)(4) business records exemption. On the one hand, a policy of unlimited disclosure might severely invade the privacy of individuals named in government-held personnel and medical files ${ }^{104}$ and might reduce the incentives of private parties to collect and produce such information in the future. ${ }^{105}$ On the other hand, a comprehensive nondisclosure approach might conceal government wrongdoing ${ }^{106}$ and might encourage the wasteful duplication of information-gathering efforts. ${ }^{107}$

In deciding cases under the FOIA (b)(6) exemption, agencies and courts have engaged in a balancing process ${ }^{108}$ instead of endorsing either a disclosure or nondisclosure outcome. ${ }^{109}$ Even

103. 5 U.S.C. $\$ 552(b)(6)(1976)$.

104. See Rural Hous. Alliance v. United States Dep't of Agriculture, 498 F.2d 73, 77 (D.C. Cir. 1974) (exemption protects individuals from "public disclosure of intimate details of their lives"); J. O'ReILLY, supra note 7, $\$ 16.01$, at 16-2 (exemption prevents government from acting as clearinghouse for detailed private information); Comment, The Freedom of Information Act's Privacy Exemption and the Privacy Act of 1974, 11 HaRv. C.R.-C.L. L. Rev. 596, 600-05 (1976) (discussing privacy interest). But see Kronman, supra note 47, at 738-41 (criticizing overconcern of courts with desire of individuals to prevent "revelation of embarrassing facts" and to avoid "unrequested solicitations").

105. See Kronman, supra note 47 , at $736-37$ (FOIA exemptions protect private information-production incentives); Posner, Privacy, Secrecy, and Reputation, 28 Bufralo L. REv. 1, 10 (1979) (secrecy is "important social instrument" for encouraging production of information).

106. See Ditlow v. Shultz, 517 F.2d 166, 172 (D.C. Cir. 1975) (disclosure of material containing personal information would allow public to assess performance of agency); 1965 SENATE REPORT, supra note 7, at 9 (highly personal information should be public knowledge in some cases); J. O'ReILly, supra note 7, § 16.07, at 16-17 (exemption ensures that agency files remain open to public scrutiny).

107. See Kronman, supra note 47, at 737-38 (disclosure of data can facilitate more efficient use of resources by making it unnecessary to collect data twice).

108. See, e.g., Department of Air Force v. Rose, 425 U.S. 352, 372 (1976) (individual's "right of privacy" balanced against need to expose agency action to "light of public scrutiny").

109. After a detailed investigation of the private and public interests involved in a particular case, a court will order disclosure (in spite of an individual's privacy claim) unless the benefits to be realized by either the requester or the public or both are clearly outweighed by the costs to be borne by either the affected individual or the public or both. Compare Columbia Packing Co., Inc. v. United States Dep't of Agriculture, 563 F.2d 495, 498-500 (1st Cir. 1977) (public interest in ensuring that agency officials acted properly before their discharge for bribery outweighs privacy interests of those officials in not having information about their careers, families, finances, and health disclosed) with Committee on Masonic Homes v. NLRB, 556 F.2d 214, 220-21 (3d Cir. 1977) (disclosure of union authorization cards of no public interest and serious invasion of employee privacy rights). 


\section{Business Records}

without express statutory authority to do so, ${ }^{110}$ courts on occasion have looked to the identity of the requesting party and the motivation behind its request. ${ }^{111}$ Courts have recognized that information made available to one party for a particular purpose under the (b)(6) exemption need not necessarily be made available to another party for a different purpose. ${ }^{112}$ Although there are differences between the (b)(4) and (b)(6) FOIA exemption contexts, ${ }^{113}$ the interpretation of the personal privacy exemption nevertheless demonstrates both that civil-discovery-type procedures are not wholly foreign to the FOIA context, and that agencies are quite capable of making rational and impartial disclosure decisions in the absence of legislatively imposed categorical constraints.

There is, moreover, a strong structural similarity between the

110. Sex 1978 FOLA REPORT, supra note 1 , at $23 \mathrm{n} .62$ (criticizing consideration of nature of requester's interest in disclosure in addition to public interest when balancing un$\operatorname{der}(b)(6))$.

111. See, e.g., Wine Hobby USA, Inc. v. IRS, 502 F.2d 133, 137 (3d Cir. 1974) (requester cannot seek (b)(6) material solely for "private commercial exploitation"); Rose v. Department of Air Force, 495 F.2d 261, 270 (2d Cir. 1974) (Moore, J., dissenting), aff'd, 425 U.S. 352 (1976) (criticizing "curiosity satisfying efforts of three law school students who [seek] merely to write a Law Review note"); Getman v. NLRB, 450 F.2d 670, 677 (D.C. Cir. 1971) (two professors-“" 'among the ablest young labor law professors'"engaged in research of "unusual promise" permitted to receive personal material otherwise private); Rabbitt v. Department of Air Force, 383 F. Supp. 1065, 1070 (S.D.N.Y. 1974) (threat to privacy balanced against requester's need for documents). But see Committee on Masonic Homes v. NLRB, 556 F.2d 214, 220 (3d Cir. 1977) (requester's private benefit from disclosure of (b)(6) document not relevant).

112. See, e.g., Getman v. NLRB, 450 F.2d 670, 677 n.24 (D.C. Cir. 1971) (information released under exemption (b)(6) may be used "only by the requesting party and for the public interest purpose upon which the balancing was based"; future request for the same information by "less well qualified applicants" would require "new balancing" with potentially different outcome). But see Ditlow v. Shultz, 517 F.2d 166, 171 \& n.21 (D.C. Cir. 1975) (criticizing Getman selective disclosure rationale); Comment, supra note 104, at 616-17 (same).

113. Ste, e.g., Westinghouse Elec. Corp. v. Brown, 443 F. Supp. 1225, 1233 (E.D. Va. 1977) (provisions on their face set forth "substantially different" tests); I965 SENATE REPORT, supra note 7, at 9 (balancing of interests explicitly authorized in (b)(6) context). Differences in the language and the legislative history of the two exemptions do not diminish the value of the (b)(6) procedure as a model. It may be argued, however, that there are fundamental differences having to do with the nature of the documents involved in the (b)(4) and (b)(6) settings. Compare R. Nader, M. Green, \& J. Seligman, Taming the Giant Corporation 138 (1976) ("privacy" is individual right and cannot be invoked to prevent disclosure of business information) with Posner, supra note 46 , at 404 (commercial secrets more deserving of confidential treatment than personal secrets). The fact that personal information may be more deserving of protection than commercial information (or vice versa) suggests not that a balancing approach is inappropriate in the (b)(4) area, but only that after the balances are struck, more commercial records will be released than business records (or vice versa). $C f$. Koch \& Rubin, supra note 12 , at 50 (both (b)(4) and (b)(6) exemptions attempt to protect rights of those who submit private information to government). 
(b)(4) and the (b)(6) situations. The typical FOIA request ${ }^{114}$ involves only two parties: an individual or organization seeks information compiled by and in the possession of a federal agency. ${ }^{115}$ In this context, because the desired document reflects directly on the performance of the agency charged with making the disclosure decision, ${ }^{116}$ it is difficult for the agency to remain neutral, and legislatively imposed constraints may be necessary in order to compensate for the agency's inevitable self-bias. ${ }^{117}$ In both the standard business records and personal privacy contexts, however, three parties are involved: one individual, organization, or business has requested information compiled and submitted to a government agency in confidence by another individual, organization, or business. ${ }^{18}$ In many cases, the agency involved has no particular stake in the disclosure outcome. ${ }^{119}$ With personal privacy matters, therefore, agencies explicitly are called upon to resolve the two parties' conflicting claims, in much the same manner as a court might balance the competing interests of litigants in civil discovery. In the business records context, however, despite this structural similarity to personal privacy requests, existing legal doctrines provide for little agency disclosure discretion.

114. Typical FOIA requests for government-held documents are those considered under exemptions (b)(1) (national security information), (b)(2) (internal agency regulations), (b)(3) (information exempt by statute), (b)(5) (agency memoranda), or (b)(7) (law enforcement records).

115. 1978 FOIA REPORT, supra note 1 , at 24.

116. See 1978 FOIA REPORT, supra note 1, at 24-25 (when disputes arise under most exemptions, requester and agency generally represent different sides of disclosure question); S. REP. No. 854, 93d Cong., 2d Sess. 3-4 (1974) (agencies withhold certain information from requesters in order to prevent political embarrassment or exposure of error and waste); Patten \& Weinstein, supra note 4, at 202 (in typical FOIA case, agency and requester are adverse parties).

117. See 1965 Senate Report, supra note 7, at 3 ("essential" that agencies be given "definitive guidelines" in order to prevent overwithholding).

118. 1978 FOIA REPORT, supra note 1 , at 24. Arguably, this three-party situation also exists with two other FOIA exemptions: (b)(8) (reports about financial institutions) and (b)(9) (geological information). Very few cases have arisen under the latter two subsections, and therefore they have been ignored throughout this Note. It has been argued, however, that any guidelines established with respect to the (b)(4) exemption could profitably be extended to govern matters arising under subsections (b)(8) and (b)(9). See 1978 FOIA REPORT, supra note 1 , at 24 .

119. See 1978 FOIA REPORT, supra note 1, at 25 (agency has no real interest in disclosure decision when its operations are unaffected by result); 1977 Senate Hearings, supra note 1, at 7, 14 (statement of Gerald P. Norton, Deputy General Counsel, FTC) (agency usually only stakeholder, with actual contest taking place between requester and submitter); English, supra note 14, at 151-52 (agency, as "stakeholder," "occupies a delicate position in the midst of the submitter's and requester's competing interests, requiring Odyssean skills to safely navigate the narrow strait between Scylla and Charybdis"). 


\section{B. Toward Resolution of the Business Records Controversy}

An alternative and more coherent approach to the reconciliation of the competing claims of disclosure and nondisclosure in the business records controversy is preferable to existing practices. This alternative approach, based in part on the civil discovery and FOIA personal privacy models, is designed to ensure that neither public nor private interests in disclosure are sacrificed unnecessarily.

Upon receipt of an FOIA request for a business document, an agency first should determine whether or not the information is exempt under subsection (b)(4). ${ }^{120}$ If nonexempt, of course, the information will be released under the FOIA's mandatory disclosure provisions. If, however, the requested document falls within the (b)(4) exemption, the agency should decide whether or not to release the material under the following procedural framework.

First, the doctrine of uncontrolled agency nondisclosure discretion should be rejected. No absolute protection should be afforded to any government-held business document requested under the FOIA. ${ }^{121}$ Rather, with respect to every such request, an agency should inquire whether or not disclosure of the document involved would be wise in light of all the available and relevant evidence. ${ }^{122}$ This inquiry should be made "on the record" 123 in order to give the requester some basis for challenging a nondisclosure decision. ${ }^{124}$

120. This determination should be made in the same manner as under existing law, that is, in accordance with the standard set forth in National Parks \& Conservation Ass'n v. Morton, 498 F.2d 765 (D.C. Cir. 1974). See note 12 supra.

121. The rejection of an absolute privilege for business documents is implicit in and consistent with the Attorney General's urging (largely ignored in the (b)(4) context) that agencies invoke FOIA exemptions only when in "the public interest." See note 29 supra.

122. It might be argued that agencies lack the resources to make the detailed, factdependent determinations called for by this Note. It should be recognized, however, that most of the additional procedures imposed upon agencies will require only a more careful examination and balancing of evidence already largely in their possession. Agencies already may have to conduct an extensive factual investigation to determine whether a document is exempt or nonexempt in the first place. See note 28 supra. Moreover, agencies can expect both the requester and the submitter to provide, upon request, information and arguments relating to a pending disclosure determination. See 1978 FOIA REPORT, supra note 1, at 28. Finally, agencies follow procedures similar to those recommended in this Note when making disclosure decisions under the (b)(6) exemption, and there is no evidence of resulting administrative overload.

123. Any lesser requirement would enable agencies to continue their current practice of rejecting FOIA requests without considering the merits of the requests and without explaining the rejection. Others have recognized the need for comprehensive administrative recordmaking in the FOIA business documents context. See U.S. Dep't of Justice, Assistant Attorney General's Memorandum, supra note 35, at 300,793; English, supra note 14, at 172.

124. A requester should be able to challenge an agency's nondisclosure decision under 
Second, Congress should eliminate those statutory provisions that unduly constrain an agency's discretion to disclose exempt business documents pursuant to an FOIA request. In particular, Congress should amend the Trade Secrets Act to make it inapplicable to FOIA business records requests. ${ }^{125}$ Disclosure decisions should be based upon an agency's case-by-case assessment of the relevant equities, and not upon an overly broad congressional mandate that, in practice, presents a virtually insurmountable obstacle to the disclosure of commercially valuable documents.

Finally, agencies should follow the balancing procedures employed successfully in the civil discovery and FOIA personal privacy settings instead of relying on categorical rules that focus only on the nature of the requested material. When considering a request for an exempt business document, an agency should assess all relevant public and private factors, including the nature of the particular document requested, the identity and purpose of the individual or organization seeking the document, ${ }^{126}$ the extent of the requester's need for the document, ${ }^{127}$ the public interest in disclosure, ${ }^{128}$ and any harm that might result to the submitter, ${ }^{129}$ the

the Administrative Procedure Act's "abuse of discretion" standard, relied upon currently by submitters who object to an agency's disclosure determination. See note 40 supra.

125. Congress should retain some provision akin to the TSA in order to punish individual federal employees who use or disclose confidential commercial information while acting outside the scope of their employment. Congress should specify, however, that the TSA and those statutes that mirror its provisions, see note 33 supra, are not to be used to bar administrative agencies from releasing business information on a discretionary basis under the FOIA. In addition, Congress should reconsider the wisdom of retaining those few nondisclosure statutes that are in fact more specific in orientation than the TSA. See note 66 supra.

126. For example, an agency should determine if the requester is a public interest organization attempting to discover whether a particular company has complied with equal employment opportunity laws, see note 2 supra, a private association seeking to determine whether an agency has unfairly awarded government franchises, see, e.g., National Parks \& Conservation Ass'n v. Morton, 498 F.2d 765 (D.C. Cir. 1974), or a competitor hoping to learn secrets about the submitter's enterprise, see note 14 supra. It may be necessary for agencies to institute an affidavit-type system (for example, a requester would be required to swear to his or her identity and to whether the request is being filed on behalf of some other individual or organization) in order to guard against the possibility that middlemen might be employed to obtain documents that ordinarily would not be made available to the party actually seeking disclosure.

127. An agency should determine whether the requested information can be obtained without undue effort or expense from an alternative source.

128. See Clement, supra note 21 , at 640 (agency should determine "beneficial functions that exempt agency information might serve in the hands of private citizens").

129. This determination will already have been made in most cases because competitive harm must be identified before a document can be declared confidential in the first place. An agency should take into account a submitter's competitive harm only; to consider other factors (such as the embarrassment or the litigation that might be visited upon a submitter as the result of disclosure) would be inconsistent with the disclosure principle. 


\section{Business Records}

agency, ${ }^{130}$ or the public ${ }^{131}$ if the document were released. All of these factors must be assessed in light of the conflicting general principles of disclosure and nondisclosure. An agency must be concerned not only with the costs and benefits to the submitter of a document and its requester, but also with the broader public interest in uncovering government corruption and business impropriety without discouraging private research and development.

If, after conducting such a balancing process, the agency decides that full disclosure is warranted, the requested document should be released. If, however, full disclosure is not warranted, the agency should undertake three additional inquiries before it ultimately decides not to disclose. First, the agency should determine whether the previously identified costs of disclosure might be eliminated or lessened by releasing the requested material in an edited form, that is, a form that does not reveal either the identity of the submitter or its more closely guarded commercial secrets. ${ }^{132}$ Second, the agency should determine whether the document could be released on the condition that the requester compensate the submitter for any commercially valuable information received, ${ }^{133}$ or released under a similar controlled scheme. ${ }^{134}$ Third, the agency could release

130. In most cases, an agency will have determined previously whether release of the requested material would impair the agency's ability to collect similar information in the future. An agency should also determine whether disclosure would assist in or detract from the attainment of its overall policy objectives. It would be inconsistent with the disclosure principle, however, for an agency to take into consideration the fact that disclosure might expose it to charges of corruption or malfeasance.

131. Under some circumstances disclosure conceivably could harm neither the submitter nor the agency, but rather a more general public interest in favor of nondisclosure, such as, for example, the need to provide incentives to produce commercially valuable information. $C f$. Richards of Rockford, Inc. v. Pacific Gas \& Elec. Co., 71 F.R.D. 388, 390 (N.D. Cal. 1976) (civil discovery denied not because it would injure party opposing discovery, but because it would undermine society's "profound interest" in allowing research scholars to keep confidentiality promises).

132. For example, in National Parks \& Conservation Ass'n v. Kleppe, 547 F.2d 673 (D.C. Cir. 1976), the court upheld an Interior Department nondisclosure decision with respect to the financial records of park concessioners on the grounds that disclosure could cause them substantial competitive injury from surrounding businesses. The agency and the court apparently failed to consider whether any of the information could have been disclosed without injury to the concessioners simply by deleting from the requested documents certain identifying material (for example, the names and locations of the concessioners). See Weinberg, supra note 83 (providing example of sanitized government-held information); $c f$. IUE v. NLRB, No. 78-2067, slip op. at 17 (D.C. Cir. Nov. 28, 1980) (in non-FOIA case, employee discrimination complaints disclosed to union in compiled form, thereby preventing identification of complaining employees).

133. St $t^{\prime}$ note 84 sufra (discussing compensated disclosure schemes).

134. For example, McGarity \& Shapiro, supra note 2, at $883-86$, propose that drug health and safety test data submitted by manufacturers to the FDA be disclosed under an "exclusive use period" arrangement. The data would be made available immediately to the 
otherwise nondisclosable material pursuant to a protective-ordertype agreement, ${ }^{135}$ with the express condition that the recipient not disseminate the material to others. ${ }^{136}$ In short, agencies should use a balancing process, selective disclosure techniques, and protective order arrangements in order to increase the amount of commercial information made available to the public under the FOIA without damaging the interests of those who submit such information to the government.

public, but competitors would not be able to use it to register competing products for a fixed period of time. $I d$. at 884. Such an arrangement presently exists under the FIFRA. See note 84 supra.

135. See note 102 supra (discussing ability to enforce administrative protective orders under existing authority). If Congress provided by statute for the use of agency-issued protective order agreements under the FOIA, an agency's power to enforce restricted-use arrangements would not be doubted. Cf. Atlas Roofing Co. v. Occupational Safety \& Health Review Comm'n, 430 U.S. 442, 450 (1977) (Congress can empower agencies with factfinding and adjudicatory functions in order to enforce statutorily created public rights).

136. For example, EEO information, see note 2 supra, might be made available to a union, an employee, or a public interest organization that wished to challenge (either informally, during collective bargaining, or in a lawsuit) a business' affirmative action efforts, so long as the recipient agreed not to make the information public. Similarly, the documents at issue in National Parks \& Conservation Ass'n v. Kleppe, 547 F.2d 673 (D.C. Cir. 1976), see note 132 supra (discussing case), could have been released to the requester upon a promise not to disclose them to any competitors of the concessioners. 